Contents list avaliable at Directory of Open Access Journals (DOAJ)
Aulad : Journal on Early Childhood
Vol 3 No 32020, Pages 126-131
ISSN : 2655-4798 (Printed); 2655-433X (Online)
Journal Homepage: https://aulad.org/index.php/aulad

\title{
Penerapan Pembelajaran Metode Eksperimen dalam Meningkatkan Kemampuan Kognitif Anak Usia 5-6 Tahun
}

\author{
Yenda Puspita ${ }^{1 凶}$ \\ Pendidikan Guru Pendidikan Anak Usia Dini, Sekolah Tinggi Keguruan dan IImu Pendidikan Aisyiyah Riau \\ DOI: $10.31004 /$ aulad.v3i3.80
}

Corresponding Author [yendapuspitah@gmail.com]

\begin{tabular}{ll}
\hline Article Info & Abstrak \\
\hline Keywords: & Penelitian ini dilatarbelakangi oleh masih rendahnya kemampuan anak dalam \\
Metode Eksperimen & mengenal konsep bilangan Di TK Hafizah Kids Pekanbaru, Perumusan masalah \\
kemampuan Kognitif & adalah Apakah terdapat peningkatan kemampuan kognitif dalam penerapan \\
Anak Usia Dini & pembelajaran metode eksperimen anak usia 5-6 tahun di TK Hafizah Kids \\
& Kecamatan Tampan?Tujuan penelitian Untuk mengetahui seberapa besar \\
& peningkatan kemampuan kognitif anak dalam penerapan pembelajaran metode \\
& eksperimen pada anak usia 5-6 tahun di TK Hafizah Kids Kecamatan Tampan. \\
& Metode yang digunakan dalam penelitian ini adalah penelitian tindakan kelas. Hasil \\
penelitian yang dilakukan, maka kesimpulan penelitian ini adalah Kemampuan & \\
Kognitif Anak usia 5 5 - 6 tahun pada data awal diperoleh skor 112 dengan \\
persentase 35.0\%, pada siklus I pertemuan 1 diperoleh skor 126 atau sebesar \\
39.4\%. pada siklus I pertemuan 2 diperoleh skor 146 atau sebesar 45.6\% dan pada \\
siklus II pertemuan 1 diperoleh skor 159 atau sebesar 49.7\% kemudian pada siklus \\
II pertemuan 2 diperoleh skor 218 atau sebesar 68.1\% dari seluruh jumlah anak.
\end{tabular}

Kata kunci: Motorik Kasar

Prasekolah

Perkembangan

Gender

Keterampilan

\section{Abstract}

This research was motivated by the low ability of children in recognizing the concept of numbers. increase in children's cognitive abilities in the application of learning experimental methods to children aged 5-6 years in Kindergarten Hafizah Kids, Tampan District. The method used in this research is classroom action research. The results of the research conducted, the conclusion of this study is the Cognitive Ability of Children aged 5-6 years in the initial data obtained a score of 112 with a percentage of $35.0 \%$, in the first cycle of meeting 1 obtained a score of 126 or equal to $39.4 \%$. In the first cycle of meeting 2 , a score of 146 or $45.6 \%$ was obtained, and in the second cycle of meeting 1 , a score of 159 or $49.7 \%$ was obtained. Then in the second cycle of meeting 2, a score of 218 or $68.1 \%$ was obtained from all children

\section{PENDAHULUAN}

Pendidikan merupakan hal yang sangat penting dan tidak bisa lepas dari kehidupan manusia. Pendidikan berfungsi membentuk kepribadian dan memahami ilmu pengetahuan. Pendidikan sangat berperan dalam membentuk baik atau buruknya pribadi manusia. Menyadari akan hal tersebut, pemerintah sangat serius menangani bidang pendidikan, sebab dengan sistem pendidikan yang baik diharapkan muncul generasi penerus bangsa yang berkualitas dan mampu menyesuaikan diri untuk hidup bermasyarakat, berbangsa, dan bernegara. Pada anak usia dini pendidikan sebagai upaya pembinaan yang ditujukan kepada anak sejak lahir sampai dengan usia enam tahun yang dilakukan melalui pemberian rangsangan pendidikan untuk membantu pertumbuhan dan perkembangan jasmani dan rohani agar anak memiliki kesiapan dalam memasuki pendidikan lebih lanjut (Indonesia, 2003). 
Dalam sistem pendidikan nasional, peserta didik terdiri dari semua warga negara, dengan arti bahwa semua satuan pendidikan yang ada harus memberikan kesempatan kepada semua warga negara yang memenuhi persyaratan tertentu sesuai khususnya tanpa membedakan status sosial, ekonomi, agama, suku bangsa, atau yang lainnya untuk menjadi peserta didiknya. Dalam proses pendidikan pada anak usia dini dikembangkan enam aspek perkembangan yaitu; kognitif, sosial emosional, bahasa, nilai agama dan moral, fisik motorik dan seni (Kementerian Pendidikan dan Kebudayaan, 2014). Dengan demikian tugas guru pada lembaga pendidikan anak usia dini adalah merangsang perkembangan anak sesuai dengan tahapannya dengan melakukan berbagai cara (Wulandari \& Purwanta, 2020).

Salah satu aspek yang dikembangkan pada anak usia dini adalah aspek kognitif. Kemampuan kognitif merupakan aspek yang dibutuhkan bagi anak dalam memperoleh, menyimpan, bahkan menerapkan suatu pengetahuan. Untuk itu, pembelajaran bagi anak harus dikemas dalam suasana bermain edukatif, menyenangkan, menumbuhkan rasa inisiatif anak (Rahmatika et al., 2019). Terkait dengan peningkatan kemampuan kognitif, Fardiah et al., (2019) mengatakan bahwa peningkatan kemampuan kognitif pada anak usia dini penting dilakukan karena berdampak pada cara berpikir di kemudian hari. Pembelajaran sains memberi dampak kepada siswa untuk berpikir logis, sistematis.

Metode eksperimen merupakan salah satu alternatif untuk meningkatkan kemampuan kognitif pada anak usia dini. Penelitian yang dilakukan Kumalasari, Ratih., Samara Putra, (2015) ditemukan bahwa metode eksperimen dengan penerapan aktivitas percobaan sederhana dapat meningkatkan perkembangan kognitif anak dan melalui metode eksperimen, akan menambah motivasi dan minat anak (Billah, 2020).

Dalam pengamatan penulis hasil belajar anak-anak di TK Hafizah Kids masih sangat kurang khususnya dalam bidang pengembangan kognitif melalui pembelajaran metode eksperimen yang diberikan oleh guru. Saat ini banyak anak TK yang belum paham dalam menerima pembelajaran, mereka bosan dan jenuh. Hal tersebut dikarenakan kualitas tenaga pendidik yang kurang mengupayakan kegiatan pembelajaran dan melakukan kegiatan eksperimen atau percobaan melalui observasi (pengamatan), penelitian (penyelidikan), dan eksperimen (percobaan). Dengan demikian dapat dikatakan bahwah hasil belajar kognitif melalui pembelajaran metode eksperimen masih dapat ditingkatkan.

Pada umumnya kegiatan eksperimen masih dominan menggunakan metode ceramah dan penugasan yang hanya di lakukan oleh guru di depan kelas secara klasikal. Hal tersebut terkesan kaku sehingga guru tidak memberi kesempatan kepada anak untuk berinteraksi dengan benda-benda konkrit. Anak kurang diberi kesempatan untuk melakukan observasi, penyelidikan, memahami sendiri dan melakukan eksperimen terhadap pembelajar konsepkonsep sains atau eksperimen melalui kegiatan nyata.

Dalam proses belajar mengajar, dengan metode eksperimen, siswa diberi kesempatan untuk mengalami sendiri atau melakukan sendiri, mengikuti suatu proses, mengamati suatu obyek, keadaan atau proses sesuatu. Dengan demikian, siswa dituntut untuk mengalami sendiri, mencari kebenaran, atau mencoba mencari suatu hukum atau dalil, dan menarik kesimpulan dari proses yang dialaminya itu. Metode eksperimen adalah metode mengajar dengan melakukan sesuatu percobaan dengan cara mengamati proses dan hasil percobaan. Widayati (2012) mengatakan metode eksperimen adalah cara penyampaian bahan ajar dimana siswa melakukan. Percobaan dengan mengalami dan membuktikan sendiri sesuatu yang di pelajarinya. Dalam proses pembelajaran dengan metode eksperimen siswa diberi kesempatan untuk mengalami sendiri atau melakukan kegiatan sendiri, mengikuti proses, mengamati suatu objek, menganalisis membuktikan dan menarik kesimpulan sendiri tentang suatu objek, keadaan atau proses tertentu. Peranan guru dalam metode eksperimen adalah memberi bimbingan agar eksperimen itu dilakukan dengan teliti sehingga tidak terjadi kekeliruan atau kesalahan.

Berdasarkan fenomena yang disampaikan peneliti di TK Hafizah Kids kecamatan Tampan di kelas B I yang berusia 5-6 tahun, anak-anak banyak mengalami kesulitan dalam pembelajaran kognitif contohnya : Rendahnya kemampuan anak dalam pembelajaran kognitif, Anak belum dapat mengungkapkan apa yang telah di coba melalui metode eksperimen, Rendahnya daya ingat anak dalam pembelajaran kognitif, Belum maksimalnya pembelajaran metode eksperimen yang digunakan dalam meningkatkan kemampuan kognitif

\section{METODE PENELITIAN}

Penelitian ini dilaksanakan di TK Hafizah Kids Kecamatan Tampan Pekanbaru tahun ajaran 2019/2020.penelitian ini dilakukan di kelompok B anak usia 5-6 tahun, Alasan memilih tempat ini adalah pertimbangan waktu dan tempat saya mengajar serta belum pernahnya dilakukan penelitian di TK Hafizah Kids. Kegiatan penelitian ini dimulai dari rumusan masalah dan menyusun proposal dan akan dilakukan setelah proposal ini diseminarkan

Metode yang digunakan adalah tindakan kelas yang peneliti lakukan pada penelitian adalah peningkatan kemampuan kognitif anak pada anak usia 5-6 tahun melalui Penerapan metode eksperimen Di TK Hafizah Kids Kecamatan Tampan Pekanbaru, dan diamati oleh observer.

Pada tahap perencanaan kegiatan yang akan dilakukan pada tempat penelitian adalah (a) menyusun program pembelajaran, (b) menyusun rencana skenario, (c) menyusun kegiatan harian, (d) membuat lembaran observasi guru dan anak, (e) menyiapkan alat peraga yang akan digunakan. Sedangkan pada tahap pelaksanaan 
tindakan dilakukan dengan melakukan mempelajari kompetensi dasar, hasil belar dan indikator setiap bidang pengembangan untuk masing-masing kelompok usia, mengidentifikasikan tema dan sub tema dan menekankannya dalam jaringan tema, mengidentifikasikan indikator pada setiap kompetensi bidang pengembangan melalui tema dan sub tema, menentukan kegiatan pada setiap bidang pengembangan dengan mengacu pada indikator yang akan dicapai dan sub tema yang akan di pilih. Pelaksanaan di laksanakan sesuai dengan langkah-langkah pembelajaran dengan model pembelajaran metode eksperimen.

Pada tahap pengamatan, peneliti mengamati hasil atau dampak dari tindakan yang dilaksanakan atau dikenakan terhadap anak. Tujuannya untuk mengetahui kualitas pelaksanaan observasi dilakukan bersamaan dengan pelaksanaan tindakan dengan melibatkan seorang pengamat yang menggunakan lembaran observasi. Adapun aspek yang diamati adalah aktifitas anak selama pembelajaran dengan menggunakan metode eksperimen.

Tahap selanjutnya adalah refleksi, peneliti mengkaji, melihat dan mempertimbangkan atas hasil atau dampak dari tindakan dari berbagai kriteria. Tujuannya adalah mengetahui kekuatan dan kelemahan dari tindakan yang dilakukan untuk dapat diperbaiki pada siklus I terlebih dahulu perlu dilakukan identifikasi masalah serta analisis dan perumusan masalah. Identifikasi masalah dapat dilakukan dengan mengajukan pertanyaan pada diri sendiri tentang pembelajaran yang dikelola, setelah masalah teridentifikasi masalah perlu dianalisis, dipilih dan dirumuskan masalah yang paling mendesak dan mungkin dipecahkan oleh guru. Masalah kemudian dijabarkan secara operasional agar dapat memandu usaha perbaikan pada siklus ke II. Setelah masalah dijabarkan , langkah berikutnya adalah mencari, mengembangkan cara perbaikan, yang dilakukan dengan mengaji teori, berdiskusi dengan teman sejawat dan pakar, serta menggali pengalaman sendiri.

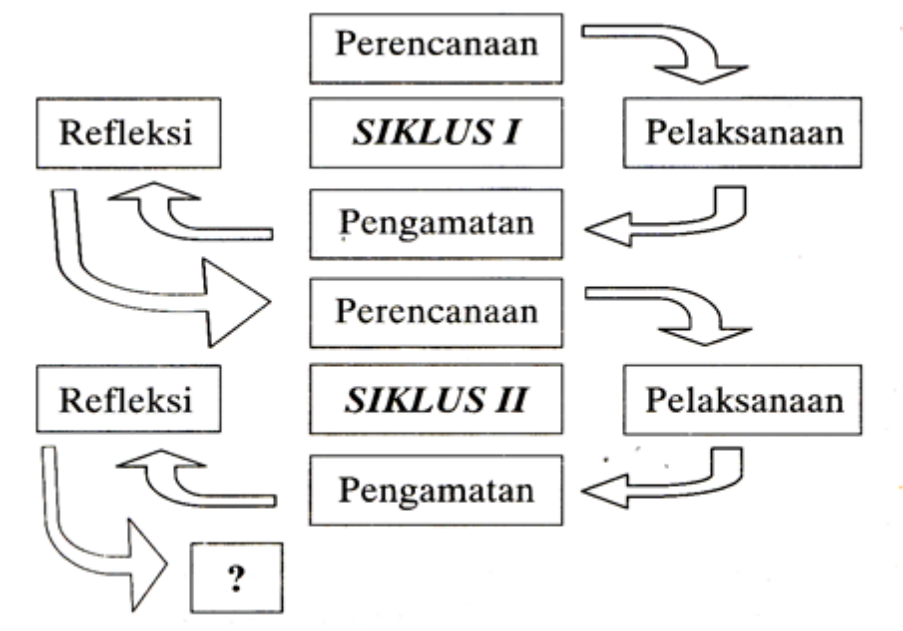

Gambar 1. Tahapan Penelitian Tindakan Kelas

\section{HASIL DAN PEMBAHASAN}

Aktivitas Anak

Dari hasil penelitian pada siklus I menunjukkan bahwa aktivitas belajar anak didik tergolong cukup baik dengan nilai $55,8 \%$, Sedangkan pada siklus II mencapai rata-rata persentase $86,2 \%$. Hal ini disebabkan oleh adanya peningkatan pada aktivitas anak didik pada seluruh indikator. Lebih jelasnya dapat dilihat pada tabel 1.

Dari tabel 1 dapat diketahui bahwa nnak memahami masalah yang akan dibuktikan melalui eksperimen pada siklus I memperoleh skor 8 atau 50,0\% dan meningkat pada siklus II menjadi 13 atau 81,3\%. peningkatan skor pada indikator Anak memperhatikan penjelasan guru adalah 31,3\%. Anak mendengarkan penjelasan dari guru tentang alat-alat dan bahan yang akan digunakan pada siklus I memperoleh skor 11 atau 68,8\% dan meningkat pada siklus II menjadi 15 atau 90,6\%. Peningkatan yang dicapai pada indikator Anak memperhatikan guru ketika mempersiapkan gambar seri adalah $21,9 \%$. Anak melaksanakan eksperimen sesuai dengan petunjuk yang diberikan guru pada siklus I memperoleh skor 7 atau 43,8\% dan meningkat pada siklus II dengan skor 13 atau 78,1 \%. Peningkatan yang dicapai pada indikator Anak memperhatikan ketika guru menunjukkan gambar seri adalah $34,4 \%$. Anak menceritakan tentang hasil yang diamati pada siklus I mencapai skor 10 atau 62,5\% dan meningkat pada siklus II menjadi 15 atau 90,6 \%. Peningkatan yang dicapai pada indikator Anak mengomentari gambar seri yang ditunjukkan oleh guru adalah $28,1 \%$. Anak tetap tertib selama guru mencatat jawaban yang di berikan pada siklus I mencapai skor 10 atau 62,5\%. Dan meningkat pada siklus II dengan skor 14 atau 87,5\%. Peningkatan yang dicapai pada indikator Anak memperhatikan arti gambar seri yang telah ditunjukkan adalah $28,1 \%$. Anak melakukan percobaan ulang agar anak yakin dengan apa yang di lihatnya pada siklus I mencapai skor 10 atau 62,5\% dan meningkat pada siklus II menjadi skor 14 atau $87,5 \%$. Peningkatan yang dicapai pada indikator Anak memperhatikan guru ketika menyimpulkan gambar seri adalah $25,0 \%$. Anak tetap semangat dalam melaksanakan eksperimen dan menerima penghargaan dari guru pada siklus I mencapai skor 7 atau $43,8 \%$ dan pada siklus II meningkat menjadi 
skor 14 atau 87,5\%. Peningkatan skor yang dicapai pada indikator Anak mengerjakan tugas dan bekerjasama dengan teman lainnya adalah $43,8 \%$.

Tabel 1. Rekapitulasi Aktivitas Belajar Anak Siklus I dan II

\begin{tabular}{|c|c|c|c|c|c|c|c|}
\hline \multirow{2}{*}{ No } & \multirow{2}{*}{ Aktivitas Anak } & \multicolumn{2}{|c|}{ Siklus I } & \multicolumn{2}{|c|}{ Siklus II } & \multicolumn{2}{|c|}{ Peningkatan } \\
\hline & & Skor & $\%$ & Skor & $\%$ & Skor & $\%$ \\
\hline 1 & $\begin{array}{l}\text { Anak harus memahami masalah yang } \\
\text { akan dibuktikan melalui eksperimen }\end{array}$ & 8 & 50.0 & 13 & 81.3 & 5 & 31.3 \\
\hline 2 & $\begin{array}{l}\text { Anak mendengarkan penjelasan dari } \\
\text { guru tentang alat-alat dan bahan yang } \\
\text { akan digunakan }\end{array}$ & 11 & 68.8 & 15 & 90.6 & 4 & 21.9 \\
\hline 3 & $\begin{array}{l}\text { Anak melaksanakan eksperimen sesuai } \\
\text { dengan petunjuk yang diberikan guru }\end{array}$ & 7 & 43.8 & 13 & 78.1 & 6 & 34.4 \\
\hline 4 & $\begin{array}{l}\text { Anak menceritakan tentang hasil yang } \\
\text { diamati }\end{array}$ & 10 & 62.5 & 15 & 90.6 & 5 & 28.1 \\
\hline 5 & $\begin{array}{l}\text { Anak tetap tertib selama guru mencatat } \\
\text { jawaban yang di berikan }\end{array}$ & 10 & 59.4 & 14 & 87.5 & 5 & 28.1 \\
\hline 6 & $\begin{array}{l}\text { Anak melakukan percobaan ulang agar } \\
\text { anak yakin dengan apa yang di lihatnya }\end{array}$ & 10 & 62.5 & 14 & 87.5 & 4 & 25.0 \\
\hline 7 & $\begin{array}{|lcr|}\text { Anak tetap } & \text { semangat } & \text { dalam } \\
\text { melaksanakan } & \text { eksperimen } & \text { dan } \\
\text { menerima penghargaan dari guru } & \end{array}$ & 7 & 43.8 & 14 & 87.5 & 7 & 43.8 \\
\hline & Jumlah & 62.5 & 390.63 & 97 & 603.1 & 34 & 212.5 \\
\hline & rata-rata & 9 & 55.8 & 14 & 86.16 & 5 & 30.4 \\
\hline & Kriteria & cuku & baik & & aik & & \\
\hline
\end{tabular}

Secara keseluruhan aktivitas belajar anak di TK Hafizah Kids Kecamatan Tampan Kota Pekanbaru, pada siklus I mencapai rata-rata 55,8\% dan pada siklus II meningkat menjadi 86,2 \%. Peningkatan untuk seluruh indikator aktivitas belajar anak di TK Hafizah Kids Kecamatan Tampan Kota Pekanbaru sebesar 30,4\%.

\section{Kemampuan Kognitif Anak usia 5 - 6 tahun}

Dengan meningkatnya aktivitas anak didik setelah penerapan metode eksperimen, terlihat pula peningkatan Kemampuan Kognitif Anak usia 5 - 6 tahun anak di TK Hafizah Kids Kecamatan Tampan Kota Pekanbaru. Perbandingan Kemampuan Kognitif Anak usia 5 - 6 tahun anak di TK Hafizah Kids Kecamatan Tampan Kota Pekanbaru dapat dilihat pada tabel 2.

Berdasarkan tabel 2 dapat dijelaskan bahwa perbandingan Kemampuan Kognitif Anak usia 5 - 6 tahun siklus I dan siklus II. Pada indikator (1) Anak dapat mengenal warna-warna primer/skunder sebelum kegiatan dimulai, dimana pada data awal hanya diperoleh skor 24 atau 37,5\% dan meningkat pada siklus I pertemuan 1 menjadi 31 atau 48,4 \%. Pada siklus I pertemuan 2 diperoleh skor 34 atau 53,1\% dan meningkat pada siklus II pertemuan 1 meningkat diperoleh skor 35 atau 54,7\% dan terakhir pada siklus II pertemuan 2 meningkat diperoleh skor 43 atau 67,2\%. Pada indikator (2) Anak berani mencoba mencampurkan warna, dimana pada data awal hanya diperoleh skor 27 atau 42,2\% dan meningkat pada siklus I pertemuan 1 menjadi 30 atau 46,9\%. Pada siklus I pertemuan 2 diperoleh skor 34 atau 53,1\% dan meningkat pada siklus II pertemuan 1 meningkat diperoleh skor 39 atau 60,9\% dan terakhir pada siklus II pertemuan 2 meningkat diperoleh skor 49 atau 76,6\%. Pada indikator (3) Anak dapat mengidentifikasikan warna baru yang ia temukan dan dasar dari warna pencampurannya pada data awal hanya diperoleh skor 24 atau 37,5\% dan meningkat pada siklus I pertemuan 1 menjadi 27 atau 42,2\%. Pada siklus I pertemuan 2 diperoleh skor 30 atau 46,9\% dan meningkat pada siklus II pertemuan 1 meningkat diperoleh skor 31 atau 48,4\% dan terakhir pada siklus II pertemuan 2 meningkat diperoleh skor 44 atau 68,8\%. Pada indikator (4) Anak dapat menemukan berbagai variasi warna baru dengan komposisi campuran warna yang berbeda-beda pada data awal hanya diperoleh skor 19 atau 29,7\% dan meningkat pada siklus I pertemuan 119 atau 29,7\%. Pada siklus I pertemuan 2 diperoleh skor 27 atau 42,2\% dan meningkat pada siklus II pertemuan 1 meningkat diperoleh skor 29 atau 45,3\% dan terakhir pada siklus II pertemuan 2 meningkat diperoleh skor 49 atau 76,6\%. Pada indikator (5) Anak dapat mengkomunikasikan temuannya pada data awal hanya diperoleh skor 18 atau 28,1\% dan meningkat pada siklus I pertemuan 1 diperoleh skor 19 atau 29,7\%. Pada siklus I pertemuan 2 diperoleh skor 21 atau 32,8\% dan meningkat pada siklus II pertemuan 1 meningkat diperoleh skor 25 atau 39,1\% dan terakhir pada siklus II pertemuan 2 meningkat dengan skor 33 atau 51,6\%. 
Berdasarkan data pada tabel 2 terlihat bahwa terjadi peningkatan kemampuan Kognitif Anak usia 5 - 6 tahun dari data awal hingga siklus II pertemuan 2. Pada data awal diperoleh skor 112 dengan persentase 35.0\%, pada siklus I pertemuan 1 diperoleh skor 126 atau sebesar 39.4\%. pada siklus I pertemuan 2 diperoleh skor 146 atau sebesar $45.6 \%$ dan pada siklus II pertemuan 1 diperoleh skor 159 atau sebesar $49.7 \%$ kemudian pada siklus II pertemuan 2 diperoleh skor 218 atau sebesar $68.1 \%$.

Tabel 2. Perbandingan Kemampuan Kognitif Anak Usia 5 - 6 tahun Sebelum Penerapan, Siklus I Pertemuan 1, Siklus I Pertemuan 2

\begin{tabular}{|c|c|c|c|c|c|c|c|c|c|c|c|}
\hline \multirow{2}{*}{ NO } & \multirow{2}{*}{ Indikator } & \multicolumn{2}{|c|}{ Data Awal } & \multicolumn{2}{|c|}{ Siklus I P 1} & \multicolumn{2}{|c|}{ Siklus I P2 } & \multicolumn{2}{|c|}{ Siklus II P 1} & \multicolumn{2}{|c|}{ Siklus II P 2} \\
\hline & & skor & $\%$ & skor & $\%$ & skor & $\%$ & skor & $\%$ & skor & $\%$ \\
\hline 1 & $\begin{array}{l}\text { Anak dapat mengenal warna-warna primer } \\
\text { sebelum kegiatan dimulai }\end{array}$ & 24 & 37.5 & 31 & 48.4 & 34 & 53.1 & 35 & 54.7 & 43 & 67.2 \\
\hline 2 & $\begin{array}{l}\text { Anak berani mencoba mencampurkan } \\
\text { warna }\end{array}$ & 27 & 42.2 & 30 & 46.9 & 34 & 53.1 & 39 & 60.9 & 49 & 76.6 \\
\hline 3 & $\begin{array}{l}\text { Anak dapat mengidentifikasikan warna baru } \\
\text { yang ia temukan dan dasar dari warna } \\
\text { pencampurannya }\end{array}$ & 24 & 37.5 & 27 & 42.2 & 30 & 46.9 & 31 & 48.4 & 44 & 68.8 \\
\hline 4 & $\begin{array}{l}\text { Anak dapat menemukan berbagai variasi } \\
\text { warna baru dengan komposisi campuran } \\
\text { warna yang berbeda-beda }\end{array}$ & 19 & 29.7 & 19 & 29.7 & 27 & 42.2 & 29 & 45.3 & 49 & 76.6 \\
\hline 5 & $\begin{array}{l}\text { Anak dapat mengkomunikasikan } \\
\text { temuannya }\end{array}$ & 18 & 28.1 & 19 & 29.7 & 21 & 32.8 & 25 & 39.1 & 33 & 51.6 \\
\hline & Jumlah & 112 & 175.0 & 126 & 196.9 & 146 & 228.1 & 159 & 248.4 & 218 & 340.6 \\
\hline & Rata-rata & 22.4 & 35.0 & 25.2 & 39.4 & 29.2 & 45.6 & 31.8 & 49.7 & 43.6 & 68.1 \\
\hline & Kriteria & & & & & & & & & & \\
\hline
\end{tabular}

Dari gambar 1 diketahui bahwa rata-rata Kemampuan Kognitif Anak usia 5 - 6 tahun dari data awal hingga siklus kedua terlihat mengalami peningkatan. Walaupun tidak seluruh anak menunjukkan peningkatan Kemampuan kognitif, tetapi penelitian dikatakan berhasil. Karena indikator kinerja telah tercapai atau melebihi $75 \%$ anak menunjukkan peningkatan Kemampuan kognitif.

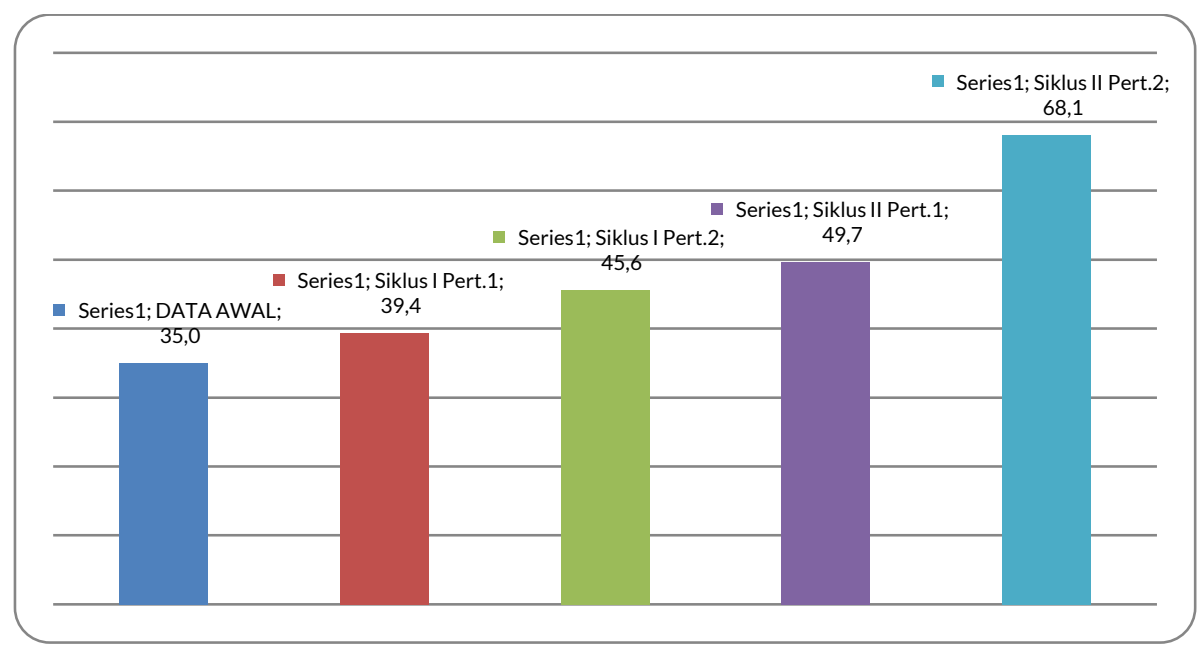

Gambar 3. Histogram Skor Dan Persentase Kemampuan kognitif anak usia 5 - 6 tahun Pada Data Awal Siklus I Pertemuan 1, Siklus I Pertemuan 2, Siklus II Siklus I dan Siklus II Pertemuan 2

\section{Pembahasan}

Hasil akhir dari penelitian tindakan kelas yang telah dilaksanakan dalam 2 siklus di TK Hafizah Kids Kecamatan Tampan Kota Pekanbaru, yang dimulai pada tanggal 18 Oktober (Siklus 1) dan 26 Oktober 2019 (Siklus 2) dengan indikator yang ingin dicapai yaitu; anak dapat mengenal warna-warna primer sebelum kegiatan dimulai, anak berani mencoba mencampurkan warna, anak dapat mengidentifikasikan warna baru yang ia temukan dan dasar dari warna pencampurannya, anak dapat menemukan berbagai variasi warna baru dengan komposisi campuran warna yang berbeda-beda, dan anak dapat mengkomunikasikan temuannya. 
Dari siklus pertama menunjukkan bahwa anak cukup tertarik dengan kegiatan eksperimen, kemampuan kognitif anak dapat ditingkatkan melalui kegiatan eksperimen mencampur warna yaitu anak dapat mengenal warna dan dapat menceritakan apa yang terjadi jika warna dicampur. Aktivitas guru dalam menerapkan Metode Eksperimen, jika pada siklus I guru sudah melakukan dengan kategori "sedang". Hal ini sesuai hasil pengamatan dimana aktivitas guru memperoleh nilai rata-rata 73,8 Hasil pengamatan aktivitas guru pada siklus II menunjukkan adanya peningkatan dengan nilai rata-rata 97,6 dengan kriteria baik. Peningkatan aktivitas guru dapat meningkatkan aktivitas anak, ini dapat dilihat bahwa aktivitas anak didik pada siklus I memperoleh skor 62,5 (55,8\%) dengan kriteria cukup baik. Terjadi peningkatan aktivitas anak didik pada siklus II dengan skor $97(86,2 \%)$ dengan kriteria baik. Peningkatan aktivitas anak didik ini diikuti oleh peningkatan Kemampuan Kognitif Anak usia 5 - 6 tahun dari siklus I ke siklus II. pada siklus I memperoleh skor $492(64,1 \%)$ dengan kriteria Cukup baik. Terjadi peningkatan Kemampuan Kognitif Anak usia 5 - 6 tahun pada siklus II dengan skor 592 (64,1\%) dengan kriteria baik.

Dari data hasil penelitian di atas dapat dikatakan bahwa kemampuan kognitif anak pada setiap anak mengalami peningkatan dari sebelum dilakukannya tindakan penelitian dibandingkan dengan setelah dilakukannya tindakan penelitian dengan menggunakan metode eksperimen. Peningkatan kemampuan kognitif anak melalui metode eksperimen tidak terlepas dari peran guru dalam merancang dan melaksanakan pembelajaran yang merupakan tanggung jawab seorang pendidik. Seorang guru yang memahami karakter dan tipe belajar anak didiknya tentu akan memilih media yang bukan hanya mempermudahnya dalam mengajar, tetapi juga membantu anak didiknya memahami pelajaran yang diberikan (Fitria \& Juwita, 2018).

Dilihat dari setiap siklus dan ketercapaian ketuntasan belajar secara klasikal, maka dengan diterapkannya metode eksperimen mencampur warna dapat meningkatkan kemampuan kognitif TK Hafizah Kids Kecamatan Tampan Kota Pekanbaru, setelah melaksanakan kegiatan eksperimen anak mengenal warna dan mengetahui hasil pencampuran warna. Sesuai dengan pendapat Sujiono \& Yuliani (2012) bahwa salah satu karakteristik perkembangan kognitif anak masa prasekolah adalah anak sudah mulai mengerti dasar-dasar mengelompokkan sesuatu atas dasar satu dimensi, seperti atas kesamaan warna, bentuk, dan ukuran. Ciri-ciri perkembangan kognitif anak usia prasekolah diantaranya adalah anak mampu mengelompokkan benda berdasarkan warna, bentuk dan ukurannya dan anak sudah mampu menghubungkan suatu konsep sederhana dengan konsep lain, misalnya dalam kegiatan mewarnai gambar anak sudah tahu bahwa tanah berwarna coklat, daun berwarna hijau, laut berwarna biru, awan berwarna putih dan seterusnya (Khadijah, 2016).

\section{SIMPULAN}

Metode Eksperimen dapat meningkatkan Kemampuan Kognitif Anak usia 5 - 6 tahun di TK Hafizah Kids Kecamatan Tampan Kota Pekanbaru. Kemampuan Kognitif Anak usia 5 - 6 tahun pada data awal diperoleh skor 112 dengan persentase $35.0 \%$, pada siklus I pertemuan 1 diperoleh skor 126 atau sebesar $39.4 \%$. pada siklus I pertemuan 2 diperoleh skor 146 atau sebesar $45.6 \%$ dan pada siklus II pertemuan 1 diperoleh skor 159 atau sebesar 49.7\% kemudian pada siklus II pertemuan 2 diperoleh skor 218 atau sebesar $68.1 \%$ dari seluruh jumlah anak..

\section{DAFTAR PUSTAKA}

Billah, A. (2020). Pendidikan Karakter Anak Usia Dini Perspektif Islam dan Implementasinya dalam Materi SAINS. In ATTARBIYAH (Vol. 2, Nomor 2). https://doi.org/10.18326/attarbiyah.v1i2.243-272

Fardiah, F., Murwani, S., \& Dhieni, N. (2019). Meningkatkan Kemampuan Kognitif Anak Usia Dini melalui Pembelajaran Sains. Jurnal Obsesi : Jurnal Pendidikan Anak Usia Dini, 4(1), 133. https://doi.org/10.31004/obsesi.v4i1.254

Fitria, Y., \& Juwita, J. (2018). Utilization of Video Blogs (Vlogs) in Character Learning in Early Childhood. Jurnal Obsesi : Jurnal Pendidikan Anak Usia Dini, 2(2), 211. https://doi.org/10.31004/obsesi.v2i2.87

Indonesia, R. (2003). Undang-undang Nomor 20 Tahun 2003.

Kementerian Pendidikan dan Kebudayaan. (2014). Permendikbud No. 137 Tahun 2014.

Khadijah. (2016). Pengembangan Kognitif Anak Usia Dini.

Kumalasari, Ratih., Samara Putra, I. W. (2015). Bidang Sains Melalui Aktivitas Percobaan Sederhana Pada Anak Kelompok B3. Jurnal Pendidikan Anak Usia Dini Undiksha, 3(1).

Rahmatika, P., Hartati, S., \& Yetti, E. (2019). Metode Pembelajaran Mind Map dan Bercerita dengan Gaya Kognitif, Pengaruhnya terhadap Kemampuan Membaca Permulaan. Jurnal Obsesi : Jurnal Pendidikan Anak Usia Dini, 3(2), 548. https://doi.org/10.31004/obsesi.v3i2.260

Sujiono, \& Yuliani, N. (2012). Konsep Dasar Pendidikan Anak Usia Dini. PT Indeks.

Widayati, A. (2012). Metode Mengajar Sebagai Strategi Dalam Mencapai Tujuan Belajar Mengajar. Jurnal Pendidikan Akuntansi Indonesia, 3(1), 66-70. https://doi.org/10.21831/jpai.v3i1.836

Wulandari, H., \& Purwanta, E. (2020). Pencapaian Perkembangan Anak Usia Dini di Taman Kanak-kanak selama Pembelajaran Daring di Masa Pandemi Covid-19. Jurnal Obsesi : Jurnal Pendidikan Anak Usia Dini, 5(1), 452. https://doi.org/10.31004/obsesi.v5i1.626 